\title{
An Efficient Hydration of Cyanamides to Substituted Ureas with Acetaldoxime as an Effective Water Surrogate
}

\author{
Sung Hwan Kim, Bo Ram Park, and Jae Nyoung Kim* \\ Department of Chemistry and Institute of Basic Science, Chonnam National University, Gwangju 500-757, Korea \\ *E-mail:kimjn@chonnam.ac.kr \\ Received November 19, 2010, Accepted November 29, 2010
}

Key Words: Hydration, Cyanamides, Ureas, Acetaldoxime, Water surrogate

Hydration of nitriles to amides is important in both academic and industrial points of view. ${ }^{1}$ The hydration reaction was performed usually in the presence of a strong acid or base catalyst, but these methods suffer from drastic conditions and overhydrolysis problem. ${ }^{2}$ Recently palladium and indium-catalyzed hydrations of nitrile to amide were developed by us using acetaldoxime as an effective water surrogate. ${ }^{\text {a-c }}$ Chang and coworkers also reported a similar hydration using acetaldoxime. ${ }^{\text {3d-f }}$ We used aqueous EtOH or toluene as solvent for the Pd(II)catalyzed hydration ${ }^{3 \mathrm{~b}, \mathrm{c}}$ and toluene in the $\mathrm{InCl}_{3}$-catalyzed reaction. ${ }^{3 \mathrm{a}}$ The weakly-activated nitrile by $\mathrm{Pd}(\mathrm{OAc})_{2}$ or $\mathrm{InCl}_{3}$ can be attacked easily by acetaldoxime to produce amide and acetonitrile as a by-product, via the six-membered transition state.

Hydration of cyanamides ( $\mathrm{RNHCN}$ or $\mathrm{R}_{2} \mathrm{NCN}$ ) to the corresponding substituted ureas is an important chemical transformation. ${ }^{4,5}$ Substituted ureas are found in many natural products, and the synthesis of ureas remains of great interest owing to their wide applications in pharmaceutical and agrochemical industry. ${ }^{4-6}$ The synthetic approaches of substituted ureas can be classified as follows: ${ }^{4-6}$ (i) reaction of amines with phosgene or its less hazardous substitutes; (ii) reaction of amines with isocyanates; (iii) insertion of CO into amino compounds; ${ }^{6 c, d}$ (iv) acid or base-catalyzed hydration of cyanamides. ${ }^{4,5}$ The hydration of nitrile moiety in cyanamide could be easier than that of organonitriles (R-CN) due to the electron-withdrawing nitrogen atom; however the reported hydration methods still required harsh reaction conditions including the use of HF-pyridine complex, ${ }^{4 \mathrm{a}} \mathrm{H}_{2} \mathrm{SO}_{4},{ }^{4 \mathrm{~b}, \mathrm{e}} \mathrm{H}_{2} \mathrm{O}_{2} / \mathrm{NaOH}^{4 \mathrm{c}}$ and $\mathrm{HCl}^{4 \mathrm{~d}}$ We envisioned that the nitrile group in cyanamide could be easily hydrated with acetaldoxime as a water surrogate in the presence of $\mathrm{InCl}_{3}$, as shown in Scheme 1.

As a model substrate, $N$-cyanoaniline (1a) was prepared by cyanation of aniline with cyanogen bromide ( $\mathrm{BrCN})$ as reported. ${ }^{7}$ The hydration conditions were examined with 1a, and the results are summarized in Table 1. The hydration of $\mathbf{1 a}$ with acetaldoxime ( 2.0 equiv) in toluene at room temperature provided a moderate yield of phenylurea (2a, 77\%) even in the absence of $\mathrm{InCl}_{3}$ (entry 1). The reaction at elevated temperature $\left(70{ }^{\circ} \mathrm{C}\right.$ ) showed lower yield of $\mathbf{2 a}$ (entry 2$)$ due to the formation of aniline and some intractable side products. The use of larger excess amounts of acetaldoxime (5.0 equiv) at slightly elevated temperature $\left(40{ }^{\circ} \mathrm{C}\right)$ raised the yield to $85 \%$ (entry 3 ). However, the yields (52-85\%) in three entries were not satisfactory. The reaction of $\mathbf{1 a}$ in the presence of $\mathrm{InCl}_{3}$ ( $3 \mathrm{~mol} \%$ ) was completed within $30 \mathrm{~min}$ even at room temperature to afford a high yield of $\mathbf{2 a}$ (entry 4). In comparison, the reaction without acetaldoxime in aqueous ethanol did not produce any trace amounts of product (entry 5). ${ }^{8}$

Thus we chose the conditions in entry 4 (Table 1), and carried out the hydration of cyanamide derivatives, as summarized in Table 2. Various cyanamides derived from arylamines (entries 1-4 and 8), alkyl amines (entries 5-7 and 9), primary amines (entries 1-3, 6, and 7), and secondary amines (entries 4, 5, 8, and 9) produced the corresponding substituted ureas in good to excellent yields ( $88-96 \%)$. Most of the entries produced the corresponding ureas at room temperature within $30 \mathrm{~min}$; however hydrations of $\mathbf{1 d}, \mathbf{1 h}$, and $\mathbf{1 i}$ were carried out at slightly elevated temperature $\left(30-40{ }^{\circ} \mathrm{C}\right)$ for $2 \mathrm{~h}$.

In summary, an efficient hydration method of various cyanamides to substituted ureas is disclosed using acetaldoxime as an effective water surrogate. The reaction was carried out in

Table 1. Optimization of reaction conditions with $N$-cyanoaniline (1a)

\begin{tabular}{clc}
\hline Entry & Conditions & Yield (\%) $^{a}$ \\
\hline 1 & $\mathrm{CH}_{3} \mathrm{CH}=\mathrm{NOH}$ (2.0 equiv), toluene, rt, $10 \mathrm{~h}$ & 77 \\
2 & $\mathrm{CH}_{3} \mathrm{CH}=\mathrm{NOH}$ (2.0 equiv), toluene, 70 ${ }^{\circ} \mathrm{C}, 2 \mathrm{~h}$ & 52 \\
3 & $\mathrm{CH}_{3} \mathrm{CH}=\mathrm{NOH}$ (5.0 equiv), toluene, $40{ }^{\circ} \mathrm{C}, 2 \mathrm{~h}$ & 85 \\
4 & $\mathrm{CH}_{3} \mathrm{CH}=\mathrm{NOH}$ (2.0 equiv), $\mathrm{InCl}_{3}(3 \mathrm{~mol} \%)$, & 95 \\
5 & toluene, rt, 30 min & 0 \\
\hline
\end{tabular}

${ }^{a}$ Isolated yield of phenylurea (2a). ${ }^{b}$ Compound 2a was observed in trace amount $(<5 \%)$ under refluxing conditions.

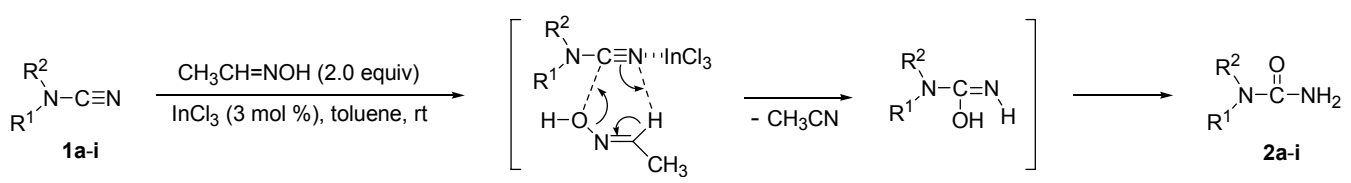


Table 2. Hydration of various cyanamides

Entry

${ }^{a}$ Conditions of $N$-cyanation: $\mathrm{BrCN}$ (2.0 equiv), $\mathrm{NaHCO}_{3}, \mathrm{PhH}, \mathrm{rt}, 2 \mathrm{~h}$. ${ }^{b}$ Conditions: $\mathrm{CH}_{3} \mathrm{CH}=\mathrm{NOH}$ (2.0 equiv), $\mathrm{InCl}_{3}$ ( $3 \mathrm{~mol} \%$ ), toluene, rt, 30 min. ${ }^{c}$ Slight warming $\left(30-40^{\circ} \mathrm{C}\right)$ for $2 \mathrm{~h}$.

toluene at room temperature in the presence of a catalytic amount of $\mathrm{InCl}_{3}$.

\section{Experimental Section}

Typical Procedure for the Synthesis of $\mathrm{N}$-Cyanamide $1 \mathrm{e}$. To a stirred mixture of L-proline benzyl ester hydrochloride (241 mg, $1.0 \mathrm{mmol})$ and $\mathrm{NaHCO}_{3}(252 \mathrm{mg}, 3.0 \mathrm{mmol})$ in benzene $(2 \mathrm{~mL})$ was added cyanogen bromide $(212 \mathrm{mg}, 2.0 \mathrm{mmol})$, and the reaction mixture was stirred at room temperature for $2 \mathrm{~h}$. After the usual aqueous workup and column chromatographic purification process (hexanes $/ \mathrm{CH}_{2} \mathrm{Cl}_{2} / \mathrm{EtOAc}, 10: 1: 1$ ), compound 1e (221 mg, 96\%) was isolated as colorless oil. Other cyanamides were prepared similarly, and the known cyanamides $\mathbf{1 a},{ }^{7 \mathrm{~d}} \mathbf{1 b},{ }^{7 \mathrm{a}} \mathbf{1 c},^{7 \mathrm{a}} \mathbf{1 d},^{7 \mathrm{~d}} \mathbf{1 f},{ }^{7 \mathrm{e}}$ and $\mathbf{1 g}^{7 \mathrm{f}}$ were characterized by comparison their IR, ${ }^{1} \mathrm{H}$ NMR and/or melting points with the reported data. The spectroscopic data of unknown cyanamides $\mathbf{1 e}, \mathbf{1 h}$, and $\mathbf{1 i}$ are as follows.
Compound 1e: 96\%; colorless oil; IR (film) 2214, 1744, $1449 \mathrm{~cm}^{-1} ;{ }^{1} \mathrm{H} \mathrm{NMR}\left(\mathrm{CDCl}_{3}, 300 \mathrm{MHz}\right) \delta 1.88-1.98$ (m, $\left.2 \mathrm{H}\right)$, $2.03-2.13(\mathrm{~m}, 1 \mathrm{H}), 2.16-2.29(\mathrm{~m}, 1 \mathrm{H}), 3.48(\mathrm{dt}, J=9.0$ and 7.2 $\mathrm{Hz}, 1 \mathrm{H}), 3.57-3.64(\mathrm{~m}, 1 \mathrm{H}), 4.26(\mathrm{dd}, J=8.4$ and $4.2 \mathrm{~Hz}, 1 \mathrm{H})$, $5.21(\mathrm{~s}, 2 \mathrm{H}), 7.33-7.39(\mathrm{~m}, 5 \mathrm{H}) ;{ }^{13} \mathrm{C} \mathrm{NMR}\left(\mathrm{CDCl}_{3}, 75 \mathrm{MHz}\right)$ $\delta 24.18,30.11,51.12,62.20,67.44,115.79,128.23,128.51$, 128.62, 134.99, 170.42; ESIMS $m / z 231\left(\mathrm{M}^{+}+\mathrm{H}\right)$. Anal. Calcd for $\mathrm{C}_{13} \mathrm{H}_{14} \mathrm{~N}_{2} \mathrm{O}_{2}$ : C, 67.81; H, 6.13; N, 12.17. Found: C, 67.98; $\mathrm{H}, 6.34 ; \mathrm{N}, 12.02$.

Compound 1h: $93 \%$; white solid, mp $81-82{ }^{\circ} \mathrm{C}$; IR (KBr) $2220,1715,1630,1597,1499 \mathrm{~cm}^{-1}$; ${ }^{1} \mathrm{HNMR}\left(\mathrm{CDCl}_{3}, 300 \mathrm{MHz}\right)$ $\delta 3.88(\mathrm{~s}, 3 \mathrm{H}), 4.54(\mathrm{~s}, 2 \mathrm{H}), 7.04-7.13(\mathrm{~m}, 3 \mathrm{H}), 7.29-7.44(\mathrm{~m}$, $7 \mathrm{H}), 8.16(\mathrm{~s}, 1 \mathrm{H}) ;{ }^{13} \mathrm{C} \mathrm{NMR}\left(\mathrm{CDCl}_{3}, 75 \mathrm{MHz}\right) \delta 45.62,52.54$, 112.47, 116.12, 123.75, 124.73, 128.94, 129.18, 129.53, 129.81, 133.85, 139.88, 146.87, 166.67; ESIMS $m / z 293\left(\mathrm{M}^{+}+\mathrm{H}\right)$. Anal. Calcd for $\mathrm{C}_{18} \mathrm{H}_{16} \mathrm{~N}_{2} \mathrm{O}_{2}$ : C, 73.95; H, 5.52; N, 9.58. Found: $\mathrm{C}$, $74.12 ; \mathrm{H}, 5.54 ; \mathrm{N}, 9.79$.

Compound 1i: 86\%; colorless oil; IR (film) 2208, 1713, $1632,1447 \mathrm{~cm}^{-1} ;{ }^{1} \mathrm{H} \mathrm{NMR}\left(\mathrm{CDCl}_{3}, 300 \mathrm{MHz}\right) \delta 3.87(\mathrm{~s}, 3 \mathrm{H})$, $3.97(\mathrm{~s}, 2 \mathrm{H}), 4.18(\mathrm{~s}, 2 \mathrm{H}), 7.20-7.23(\mathrm{~m}, 2 \mathrm{H}), 7.28-7.37(\mathrm{~m}, 8 \mathrm{H})$, $8.03(\mathrm{~s}, 1 \mathrm{H}) ;{ }^{13} \mathrm{C} \mathrm{NMR}\left(\mathrm{CDCl}_{3}, 75 \mathrm{MHz}\right) \delta 46.03,52.38,55.72$, $117.28,125.85,128.46,128.48,128.71,128.75,129.14,129.42$, 133.86, 134.54, 145.75, 167.07; ESIMS m/z $307\left(\mathrm{M}^{+}+\mathrm{H}\right)$. Anal. Calcd for $\mathrm{C}_{19} \mathrm{H}_{18} \mathrm{~N}_{2} \mathrm{O}_{2}$ : C, 74.49; $\mathrm{H}, 5.92 ; \mathrm{N}, 9.14$. Found: $\mathrm{C}$, $74.41 ; \mathrm{H}, 6.17 ; \mathrm{N}, 9.09$.

Typical Procedure for the Hydration of 1e. To a stirred mixture of $1 \mathrm{e}$ (115 mg, $0.5 \mathrm{mmol}$ ) and acetaldoxime (60 mg, 1.0 mmol) in toluene $(1.5 \mathrm{~mL})$ was added $\mathrm{InCl}_{3}(3 \mathrm{mg}, 3 \mathrm{~mol} \%)$ and stirred at room temperature for $30 \mathrm{~min}$. Most of $2 \mathbf{e}$ was deposited during the reaction, and the solid product was filtered and washed with $\mathrm{CH}_{2} \mathrm{Cl}_{2}$ to afford analytically pure product, $82 \mathrm{mg}$. Additional 2e (36 mg) was isolated from the washings and filtrates by column chromatography $\left(\mathrm{CH}_{2} \mathrm{Cl}_{2} / \mathrm{EtOAc} / \mathrm{MeOH}\right.$, $25: 3: 1)$. Total amount of $2 \mathrm{e}$ was $118 \mathrm{mg}(95 \%){ }^{9}$ Other urea derivatives were prepared similarly and characterized by comparison their IR, ${ }^{1} \mathrm{H}$ NMR and/or melting points with the reported data. $5 \mathrm{c}, 6 \mathrm{e}, 6 \mathrm{~g}, 9$

Acknowledgments. This research was supported by the Basic Science Research Program through the National Research Foundation of Korea (NRF) funded by the Ministry of Education, Science and Technology (2010-0015675). Spectroscopic data were obtained from the Korea Basic Science Institute, Gwangju branch.

\section{References and Notes}

1. (a) Thallaj, N. K.; Przybilla, J.; Welter, R.; Mandon, D. J. Am. Chem. Soc. 2008, 130, 2414-2415. (b) Bokach, N. A.; Kukushkin, V. Y. Russ. Chem. Rev. 2005, 74, 153-170. (c) Kukushkin, V. Y.; Pombeiro, A. J. L. Inorg. Chim. Acta 2005, 358, 1-21. (d) Larock, R. C. Comprehensive Organic Transformations, 2nd ed.; Wiley-VCH: New York, 1999; p 1988.

2. (a) Moorthy, J. N.; Singhal, N. J. Org. Chem. 2005, 70, 1926-1929 and further references cited therein. (b) Berrien, J.-F.; Royer, J.; Husson, H.-P. J. Org. Chem. 1994, 59, 3769-3774. (c) Katritzky, A. R.; Pilarski, B.; Urogdi, L. Synthesis 1989, 949-950. (d) Hall, J. H.; Gisler, M. J. Org. Chem. 1976, 41, 3769-3770. (e) McIsaac, J. E., Jr.; Ball, R. E.; Behrman, E. J. J. Org. Chem. 1971, 36, 30483050. (f) Merchant, K. J. Tetrahedron Lett. 2000, 41, 3747-3749. 
3. For the hydration of nitriles to amides with the aid of acetaldoxime, see: (a) Kim, E. S.; Lee, H. S.; Kim, S. H.; Kim, J. N. Tetrahedron Lett. 2010, 51, 1589-1591. (b) Kim, E. S.; Lee, H. S.; Kim, J. N. Tetrahedron Lett. 2009, 50, 6286-6289. (c) Kim, E.; S.; Kim, H. S.; Kim, J. N. Tetrahedron Lett. 2009, 50, 2973-2975. (d) Lee, J.; Kim, M.; Chang, S.; Lee, H.-Y. Org. Lett. 2009, 11, 5598-5601. Chang and co-workers reported an efficient Rh-catalyzed conversion of aldoxime to amide, with a nitrile additive for the rate acceleration. Activated nitrile by Rh catalyst played an important role in the conversion, see. (e) Kim, M.; Lee, J.; Lee, H.-Y.; Chang, S. Adv. Synth. Catal. 2009, 351, 1807-1812. (f) Park, S.; Choi, Y.-a.; Han, H.; Yang, S. H.; Chang, S. Chem. Commun. 2003, 1936-1937.

4. For the hydration of cyanamide to urea under acid or base-catalyzed conditions, see: (a) Nirschl, A. A.; Zou, Y.; Krystek, S. R., Jr.; Sutton, J. C.; Simpkins, L. M.; Lupisella, J. A.; Kuhns, J. E.; Seethala, R.; Golla, R.; Sleph, P. G.; Beehler, B. C.; Grover, G. J.; Egan, D.; Fura, A.; Vyas, V. P.; Li, Y.-X.; Sack, J. S.; Kish, K. F.; An, Y.; Bryson, J. A.; Gougoutas, J. Z.; DiMarco, J.; Zahler, R.; Ostrowski, J.; Hamann, L. G. J. Med. Chem. 2009, 52, 2794-2798. (b) Jadhav, V. D.; Herdtweck, E.; Schmidtchen, F. P. Chem. Eur. J. 2008, 14, 6098-6107. (c) Schade, D.; Topker-Lehmann, K.; Kotthaus, J.; Clement, B. J. Org. Chem. 2008, 73, 1025-1030. (d) Haufe, G.; Rolle, U.; Kleinpeter, E.; Kivikoski, J.; Rissanen, K. J. Org. Chem. 1993, 58, 7084-7088. (e) Jung, S.-H.; Kohn, H. J. Am. Chem. Soc. 1985, 107, 2931-2943.

5. For the hydration of cyanamide to urea via a neighboring group participation, see: (a) Snider, B. B.; Duvall, J. R. Org. Lett. 2005, 7, 4519-4522. (b) Duvall, J. R.; Wu, F.; Snider, B. B. J. Org. Chem. 2006, 71, 8579-8590. (c) Nag, S.; Yadav, G. P.; Maulik, P. R.; Batra,
S. Synthesis 2007, 911-917.

6. For the general synthesis of urea derivatives, see: (a) Artuso, E.; Degani, I.; Fochi, R.; Magistris, C. Synthesis 2007, 3497-3506 and further references cited therein. (b) Degani, I.; Fochi, R.; Magistris, C.; Migliaccio, M. Synthesis 2009, 801-808. (c) Peng, X.; Li, F.; Xia, C. Synlett 2006, 1161-1164 and further references cited therein. (d) Zheng, S.; Peng, X.; Liu, J.; Sun, W.; Xia, C. Helv. Chim. Acta 2007, 90, 1471-1476. (e) De Luca, L.; Porcheddu, A.; Giacomelli, G.; Murgia, I. Synlett 2010, 2439-2442. (f) Liu, Q.; Luedtke, N. W.; Tor, Y. Tetrahedron Lett. 2001, 42, 14451447. (g) Lee, C. G.; Gowrisankar, S.; Kim, J. N. Bull. Korean Chem. Soc. 2005, 26, 481-484.

7. For the synthesis of cyanamides, see: (a) Kaupp, G.; Schmeyers, J.; Boy, J. Chem. Eur. J. 1998, 4, 2467-2474. (b) Singh, V.; Hutait, S.; Batra, S. Eur. J. Org. Chem. 2009, 3454-3466. (c) Nag, S.; Mishra, A.; Batra, S. Tetrahedron 2008, 64, 10162-10171. (d) Wu, Y.-q.; Limburg, D. C.; Wilkinson, D. E.; Hamilton, G. S. Org. Lett. 2000, 2, 795-797. (e) Cai, T.; Xian, M.; Wang, P. G. Bioorg. Med. Chem. Lett. 2002, 12, 1507-1510. (f) Kumar, V.; Kaushik, M. P.; Mazumdar, A. Eur. J. Org. Chem. 2008, 1910-1916. (g) Ghosh, H.; Yella, R.; Ali, A. R.; Sahoo, S. K.; Patel, B. K. Tetrahedron Lett. 2009, 50, 2407-2410.

8. The reaction of $1 \mathbf{a}$ in aqueous EtOH did not produce $\mathbf{2 a}$ even in the presence of acetaldoxime, and the reason is not clear at this stage. The hydration of cyanamide can be performed under solvent-free conditions. As an example, the reaction of $1 \mathrm{a}$ and acetaldoxime (3.0 equiv) at room temperature in the presence of $\mathrm{InCl}_{3}$ ( $3 \mathrm{~mol} \%$ ) afforded $\mathbf{2 a}$ in $91 \%$ yield.

9. Kurokawa, M.; Shindo, T.; Suzuki, M.; Nakajima, N.; Ishihara, K.; Sugai, T. Tetrahedron: Asymmetry 2003, 14, 1323-1333. 